FOLIA SCANDINAVICA VOL. 23 POZNAŃ 2017 DOI: $10.1515 / \mathrm{fsp}-2017-0009$

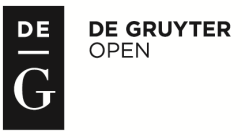

PRESSto.

\section{MIGRATIONSERFARINGEN \\ I DE POLSK-DANSKE FORFATTERES VÆRKER}

\author{
SYLWIA IZABELA SCHAB
}

Adam Mickiewicz University in Poznań

ABSTRACT. The aim of the article is to analyze works written by four Polish-Danish authors in terms of defining the poetics they use to communicate their migration experience. The migration experience is to be understood as a never-ending process of translating own identity to a new cultural context. The point of departure for the analysis are selected works of four Polish-Danish authors: Alicja Fenigsen, Janina Katz, Bronisław Świderski and Grzegorz Wróblewski. The author of the article discusses also the existence/ non-existence of a specific Polish-Danish migration aesthetic by comparing the analyzed works.

"Har vi en migrantlitteratur og hvorfor ikke?" spurgte Hans Hauge i en kronik i 2014, hvor han efterspurgte litteratur skrevet af indvandrere på det danske bogmarked. Han mente dermed den litterært bearbejdede erfaring fra ikke etniske danskere, som ville være synlig "i den institution, der hedder dansk litteratur" (ibid) ${ }^{1}$. Gayatri Spivaks kanoniserede spørgsmål "Can the Subaltern Speak?" er en mulig måde at problematisere dette fænomen på, man kan dog også diskutere selve begrebet "indvandrer/migrantlitteratur" som nøglen til problemet med ikke at kunne finde denne kategori i dansk litteraturhistorieskrivning.

Spørgsmålet om indvandrer-/migrant-/migrationslitteratur ${ }^{2}$ blev aktualiseret i 2013, da Yahya Hassans digtsamling udkom og vakte en hidtil ukendt interesse omkring en litterær debut i Danmark. Det iøjnefaldende i receptionen af Digte var, at de danske anmeldere har læst dem med indvandrerpolitiske briller

\footnotetext{
${ }^{1}$ Se Søren Frank (2013a), hvor han argumenterer for "the non-existence and the existence of migrant writers".

${ }^{2}$ Begreberne kommer jeg tilbage til senere i artiklen.
} 
(frem for litteraturkritiske, jf. Schab 2016). Den blev dermed læst stærkt reducerende - rettere som en stemme i samfundsdebatten end som et kunstnerisk værk. "Y Factor", som Lars Bukdahl (2014) kaldte fænomenet (både det litterære og det, der er forbundet med digteren som person), er langt fra det eneste eksempel på dansk litteratur skrevet fra "et tomrum" (Aidt 2007:8). Alligevel er de andre forfattere med indvandrerbaggrund ikke nået til et bredt dansk publikum og forbliver i en læserniche ${ }^{3}$.

I det følgende vil jeg fokusere på fire forfattere af polsk afstamning, som er bosat i Danmark: Alicja Fenigsen, Janina Katz, Bronisław Świderski og Grzegorz Wróblewski. Jeg vil læse deres forfatterskaber med fokus på, hvordan de italesætter migrationserfaringen, dvs. de elementer som er forbundet med det at skulle forlade sit hjemland og leve i Danmark. Migrationserfaringen definerer jeg i denne artikels kontekst som et aldrig afsluttet forsøg på at oversætte sit gamle jeg til sine nye jeg-er, det at kunne få styr på sin flydende, omdefinerbare, ikkefaste identitet. Min fremgangsmåde vil være at identificere de poetikker, forfatterne tager i brug, når de konfronterer deres hovedpersoner med den fremmede danske virkelighed. Jeg læser dermed udvalgte værker (se litteraturlisten) for at identificere den måde, migrationserfaringen kommer til udtryk på. Da Lars Wendelius i 2002 skrev om immigrant- om minoritetslitteratur på svensk fra 1970-2000, pegede han på de tematiske mønstre, som går igen i de værker, han regner med til denne kategori. Det var bl.a.: billedet af Sverige, drømmen om hjemlandet, nationen, historien og jeget, kulturmødet og den dobbelte identitet (Wendelius 2002:71 ff.). Jeg stiller også spørgsmålet, om disse mønstre ligeledes forekommer i de dansk-polske værker og dermed - om der muligvis kan være tale om et generelt mønster, som kunne identificeres som en slags (polsk) litterær indvandreræstetik/migrationsæstetik.

\section{BEGREBER}

Men hvad med selve begrebet "indvandrerlitteratur"? Som Hans Hauge (2014) påpeger, har man afskaffet det i Sverige - efter at den første indvandrerroman udkom i 2003 (Khemiris Et øje rødt). I hvert fald som en genrebetegnelse, hvor indvandrerlitteratur fungerer som en ekskluderende størrelse, der kun omfatter litteratur skrevet af forfattere med en anden etnisk

${ }^{3}$ Danmark har mange flere - ikke helt synlige - forfattere med udenlandsk baggrund (eller "interkulturelle forfattere", som Søren Frank kalder dem for, 2013b:105) end Yahya Hassan, for bare at nævne Mëir Aaron Goldschmidt, Henri Nathansen, Edvard Brandes (kaldt for "fortidens indvandrerforfattere" af Hans Hauge 2013, se også Thing 2013), William Heinesen, JørgenFrantz Jacobsen eller Axel Sandemose. Mange flere kom til i efterkrigstiden, bl.a.: Maria Giacobbe, Rubén Palma, Adil Erdem, Alen Mešković, Lone Aburas, Maja Lee Langvad og Eva Tind. 
baggrund (hvor fødested, biografi eller nationalitet bliver til den afgørende kategori, og hvor der søges (findes?) den form for autenticitet, som ingen indfødte forfattere kan præstere). Magnus Nilsson (2010) diskuterer desuden det problematiske ved at forstå indvandrerlitteratur som et udtryk for etnisk kultur og identitet. Han argumenterer for, at "repræsentationen af etniske erfaringer og identiteter i de svenske indvandreres værker er en følge af den diskursive konstruktion af indvandrerlitteratur-kategorien" (Nilsson 2010:201). Indvandrerlitteraturen forstås som en diskursiv kategori, som både påvirker produktion og reception af litterære værker, og den forbindes med autenticitetsforventningen til værkerne. Autenticiteten garanteres af selve forfatteren og hans/hendes biografi samt af indvandrertematikken, herunder den dobbelte identitet. Receptionen af indvandrerlitteraturen bliver underordnet det, som Thomas Mohnike kalder for "der etnographische Blick", og er rettet mod det, der er anderledes og eksotisk; indvandrerlitteraturen skulle give et etnografisk indblik i den sociale virkelighed og være et medium, som formidler "forestillinger om kulturel fremmedhed og nærhed" (Mohnike 2007:241).

Forfatterne selv er heller ikke glade for at få etiketten som indvandrerforfattere, da kategorien synes at være meget begrænsende (se fx Yahya Hassans udtalelser). Det problematiske er også, at - som Frank (2013b:126) påpeger: "Indvandrerlitteraturen læses ikke som kunst, men som debatindlæg.". Ud fra et andet nationalt perspektiv opfattes desuden de værker, som jeg har omtalt, som emigrantlitteratur eller "polsk udenlandsk litteratur" (se fx Zduniak-Wiktorowicz 2010).

Søren Frank argumenterer for at anvende migrationsbegrebet i stedet. Hans udlægning af begrebet peger på forandring, bevægelse og proces, og begrebet forstås som "ikke begrænset til spacial bevægelse", mens det også "henviser (...) til temporale og mentale processer" (Frank 2012:6). Migration og migrationslitteratur forstås dermed således, at fokusset fjernes fra det biografiske element, som er konstituerende for begreberne indvandrerlitteratur og migrantlitteratur. Migrationslitteraturens ambition skulle være

(...) at centrifugalisere de personlige, kulturelle og nationale identiteter (...) såvel som at bringe de interne forskelle frem i forgrunden med henblik på at kontrastere de monokulturelle billeder af nationen og dets befolkning med kosmopolitiske, mudrede billeder. (Frank 2012:7)

Migrationslitteraturens "formelle hjemløshed" viser sig gennem "vagabonderende perspektiver", "en stemmes fremmedhed", "gennem lingvistisk urenhed og heteroglossia" og gennem "ufuldendte, multidimensionale og rhizomatiske kompositioner" (Frank 2012:8). Hvis man følger (og accepterer) denne tankegang (som undertegnede gør), kan de fire præsenterede forfattere kategoriseres som migrationsforfattere. Ifølge Kim Simonsens kategorisering (Simonsen 2013:147) kan de beskrives som "voksne og anerkendte migrant- 
forfattere" (Katz, Wróblewski og Fenigsen) og "migrantforfattere, som skriver på deres modersmål og er anerkendt i deres hjemlande" (Świderski, Wróblewski). I det følgende vil jeg således også sætte fokus på de ikke"eksotiske" aspekter ved de polsk-danske forfatteres værker, dvs. ikke forbundet med den etniske kontekst. Det ikke at læse dem reducerende kan afsløre den dimension, der er forbundet med den universelle transgressionserfaring, det flydende og det ustabile som selve tilværelsens præmis.

\section{FORFATTERNE OG DERES MIGRATIONSPOETIKKER}

\subsection{KAOS, MISFORSTÅELSER OG ENSOMHED - ALICJA FENIGSEN}

Alicja Fenigsen (f. 1949) flyttede til Danmark i 1969, som følge af den tiltagende antisemitiske stemning i Polen under det kommunistiske styre. Hun blev færdiguddannet på Kunsthåndværkerskolen i 1974, har arbejdet som aftenskolelærer og tolk samt været aktiv som billedkunstner. I 1982 debuterede hun med romanen Der var så meget, som efterfulgtes af $O g$ på den anden side (1989). Begge romanerne er selvbiografisk inspirerede og tematiserer en ung polsk-jødisk kvindes liv i Danmark. Den sidste kan også læses som en slags kollektiv roman - persongalleriet omfatter (ud over polakken Anna, som er vendt tilbage til Danmark efter et mislykket ophold (og forhold?) i USA) også andre kvinder som tante Mania og niece Kasia, men også polakken Jasio, billedkunstneren, der fører en omflakkende tilværelse, som læseren også møder i den første roman. Hovedpersonen i den første roman - den politiske flygtning Felicia (som også kommer i en scene i $O g$ på den anden side) er ved at opbygge sit liv i Danmark, hvor hun har bosat sig efter at hun måtte forlade Polen i 1969 som nittenårig. Hendes livsprojekt handler om at blive integreret, om at blive som de fredfulde, afslappede danskere, hun møder:

Hvis jeg prøvede at gøre alt, hvad de plejede at gøre, kunne jeg måske en dag blive ligesom de, med deres lette skridt og yndefulde kroppe. (Fenigsen 1982:13)

Hun har lært dansk, men har fortsat svært ved den figurative del af sproget ("Alle disse vittigheder, der skal forklares, vendinger, der skal dræbes og dissekreres for at kunne forstås, igen og igen.”, Fenigsen 1982:9). Hun har fået en bolig og arbejder på et plejehjem. Og dog konfronteres hun gang på gang med sin kulturelle fremmedhed, hvis tydeligste tegn er sproget. Hun bliver spurgt om sit hjemland, om hun godt kan lide at være i Danmark, om hvad hun savner mest - spørgsmål, som måske er velmente, men som hun også bliver træt af ("(...) jeg er bare så træt af disse samtaler. Der er altid det samme, hver gang.”, Fenigsen 1982:38). Konfrontationen er ikke desto mindre selve forfatterens primære strategi $i$ hendes polsk-danske narrativ. Hun sammenstiller det hjemlige - det polske og det nye - det danske i hovedpersonens refleksioner, 
i dialogerne, i retrospektiverne, men også ved at skildre det polske miljø i København. Hovedpersonen Felicia påtager sig et missions- eller forkyndelsesarbejde, træder i rollen som det heldige vidne, der overlevede:

Til at begynde med bildte jeg mig ind at det var min opgave at være vidne, at fortælle hvad jeg havde oplevet, de politiske ting, hvorfor vi pludselig skulle rejse hjemmefra, hvordan det var muligt at middelalderen var over os igen, med heksejagt og jødeforfølgelser. (Fenigsen 1982:50).

På trods af sin aktive og integrerende attitude havner hoverpersonen i den situation, hvor hun er dømt til en limboagtig tilstand, hvor hun bliver sat i et rum ind imellem - in-between - det at være hverken derfra eller herfra, eller være fra begge steder samtidig i en kaotisk sammenvævning af forskelligartede identiteter, trofastheder, traditioner og forventninger. Felicia prøver at få en fastere forankring gennem et parforhold, at slå rod, at finde lykken, som er "en våbenstilstand med livet, en fred, der gør, at man ikke længere længes efter et helt andet slags liv" (Fenigsen 1982:73 f.), men mislykkes også på kærlighedsfronten. Det polske miljø i København er heller ikke det sted, som hjælper hende med at genfinde sin integritet, for det er heller ikke koherænt, og dets fællesnævner er "vores nationalsport: fortidsdyrkelsen, som samtidig er ulykkens dyrkelse" (Fenigsen 1982:117). Stemningen i romanen bliver mere dyster mod slutningen, hvor Felicias forhold med danskeren Hans krakelerer på grund af den rådvildhed, som hun hverken er i stand til at rumme, formidle eller til at lægge en dæmper på. Felicias fortvivlelse mødes med de fremmedfjendske undertoner i det danske samfund, og hun overtager glimtvis de fremmedfjendske danskernes syn på sig selv:

Jeg er jøde, polak, flygtning, dansk statsborger... (...) Jeg er stinkdyret, fejlfarven, jøden, tyrken, pakien? Jeg er snakkesaligt sjask liv ude i det ydre rums kulde. (Fenigsen 1982:170)

Den overordnede narrative strategi i $O g$ på den anden side adskiller sig ikke mærkbart fra den, som er blevet anvendt i Der var så meget. Hovedpersonerne er polske flygtninge og indvandrere fra tre generationer og deres hjemland gennemgår igen store omvæltninger (her er det krigsretstilstanden fra 1981, som er romanens baggrund). Den dominerende livserfaring for romanens personer er ensomheden, der præsenteres som en del af en indvandrers eksistentielle præmisser. Det at være indvandrer er et "liv i forklædninger" (Fenigsen 1989:38), man er bragt ude af balance og det eneste faste, man kan opnå, er at blive "anbragt, placeret, forankret og udsat" (Fenigsen 1989:51). Ensomheden forstærkes af den gennemgribende følelse af ikke at blive forstået, som bygger på epistemologiske præmisser: 
Det er klart at de i virkeligheden ingen mulighed har for at forstå de verdener andre kommer fra, ingen reelle chancer for at vurdere deres forklaringer. (Fenigsen 1989:83)

Romanerne dokumenterer migranternes umulige identitetsbaserede situation de er overgangsfigurer, for hvem det er umuligt at tage et skridt frem, men det er heller ikke muligt at komme tilbage til deres fortids land. De er dømt til en eksistentiel dobbelthed og til at virke som kontaktpersoner mellem to verdener (som fx tolke for andre asylansøgere), som dog aldrig helt kommer til at forstå hinanden.

\section{2. "EN KALV MED TO HOVEDER" - JANINA KATZ}

Janina Katz (1939-2013) var en polsk-jødisk indvandrer, bosat i Danmark siden 1969, som debuterede på dansk 22 år efter at hun kom til Danmark som 52-årig (1991, digtsamlingen Min moders datter). Hun havde ikke udgivet værker på polsk før, men dog oversat polske digtere til dansk ${ }^{4}$. Hun er forfatter til 15 digtsamlinger (den sidste udgivet posthumt), 5 romaner, 2 novellesamlinger og en børnebog. Hun er den eneste, som nød anerkendelse som forfatter i Danmark: hendes første roman Mit liv som barbar blev Årets Bedste Roman i 1993, i 2002 fik hun Statens Kunstfonds livsvarige ydelse, og sidst men ikke mindst blev hun i 2012 nomineret til Nordisk Råds Litteraturpris som repræsentant for Danmark for digtsamlingen Skrevet på polsk.

I sine værker vender hun tilbage til sin barndom under krigen og ungdom i efterkrigstidens Polen (som fx i romanerne Mit liv som barbar, 1993, Putska, 1997 og Drengen fra dengang, 2004), hun tematiserer det komplekse ved at være jøde og polak ("En evig jøde/En tapper polak" som det hedder i digtet "Morgenbesøg" fra debutsamlingen Min moders datter, 1991:73), ved at være indvandrer og rodløs, ved ikke rigtig at høre til nogen steder. Det specifikke og ret udprægede aspekt af den eksistentielle hjemløshed vedrører sproget. Jeget i Katz' digte giver udtryk for at være hjemløs fra sprog og samtidig at være sit modersmål utro ('Har lige kopuleret med en vildt fremmed. Med barbariske gloser.’, 1991:80). Jeget føler sig som en tyv, når hun bruger dansk (se digtet "Jeg er en tyv", 1991:83). Katz beskriver erfaringen med at være tosproget som at være "en kalv med to hoveder" ("en kalv/med to hoveder/der ikke sidder/fast nok/og derfor/nikker/til hinanden/vemodigt.", 1991:78). Tosprogetheden opfattes ikke som nogen triumf, snarere som en unaturlig situation, her udtrykt gennem uhyremetaforen. Men tosprogetheden fremstår heller ikke som nogen splittelse - "Snarere/som ens ældste og bedste vens/uundgåelige for-

${ }^{4}$ Det gælder Nobelpristagere Czesław Miłosz og Wisława Szymborska, samt Ewa Lipska, Tadeusz Różewicz og andre, som fx Grzegorz Wróblewski. 
svinden./Og i stedet for:/to gode bekendte." (ibidem) - der er rettere tale om en delvis død.

Katz trækker helt klart på det selvbiografiske - det gælder både hendes digte og romaner. Men hendes værker rummer meget mere end indvandrererfaring - de italesætter det komplicerede barn-mor-forhold, kredser omkring gud og tro (eller mangel på samme), kommer ind på ensomhed, angst, smerte, kærlighed, længsel og tab, henviser til Polen, Danmark og Israel, som er blevet til et imaginært drømmehjemland. De er fulde af humor og selvironi og faktisk ikke sentimentale eller nostalgiske. I en bred vifte af emner og motiver transcenderer skæbnefortælleren Katz helt klart det "kun" at være en indvandrerforfatter, som bare giver et vidnesbyrd om sin skæbne og om livet i et nyt land, og som minder, sammenligner, kritiserer eller lovpriser. Hun taler fra en barbars sted, hvor barbaren (i sin oprindelige betydning den, der ikke kan tale ordentligt) dog vel at mærke mestrer det nye sprog. Samtidig har Katz et dobbelttydigt forhold til dansk: det er jo det sprog, som gjorde, at hun blev digter og forfatter, men også det sprog, hvor hun "ruller uhyggeligt på r'erne" (fra digtet "Morgenbesøg", 1991:72), altså et fremmed sprog, som identificerer hende som en fremmed, og som er "et mareridt af et sprog. En ondsindet lingvists hikkende drøm" (Christensen, 2015), som hun har udtrykt det i et interview ${ }^{5}$.

Danske literaturkritikere og -anmeldere var ikke blinde for de kunstneriske kvaliteter i Katz' forfatterskab. De kalder hende for "en stor dansk forfatter" (Blüdnikow 2005) og "en stor digter" (Skyum-Nielsen 2011), "en af de allerbedste lyrikere, man har set på den danske scene i de sidste 10 år" (Larsen 2006), men også en, som fortsætter den fornemme dansk-jødiske tradition i Goldschmidts og Nathansens spor (Blüdnikow 2005).

\subsection{FEJL OG OVERSÆTTELSE SOM DEN FREMMEDES LIVSPRÆMISSER - BRONISŁAW ŚWIDERSKI}

Bronisław Świderski (født 1946) kom til Danmark et år senere end Janina Katz, men af de samme grunde - nemlig antisemitisme, som kulminerede i Polen i 1968. Han har i mange år arbejdet som forsker på Københavns Universitet og Søren Kierkegaard Forskningscenteret, har også oversat Kierkegaard til polsk. Świderski debuterede i 1981 med en kortroman Autobiografie [Selvbiografier] udgivet i London. Han er en kendt skribent og essayist og har samarbejdet med en række polske tidsskrifter og dagblade (og hans skifter blev udgivet i en samlet publikation i Poznań i 2012 (på 500 sider) under titlen Kiedy moge zabić? Dyskusje o kulturze i przemocy [Hvornår må jeg slå ihjel? Diskussioner om kultur og vold]). Han er også forfatter til to romaner, som

${ }^{5}$ Om det sproglige aspekt i Katz’ debutdigtsamling, se Stoubæk (2012:102 ff.). 
begge er blevet indstillet til Polens fornemste litteraturpris - Nikeprisen. De to sidstnævnte værker Stowa obcego [Den fremmedes ord] fra 1998 og Asystent śmierci [Dødens assistent] fra 2007 har begge to en hovedperson, som er udlænding af polsk-jødisk afstamning og bosat i Danmark (B. i Stowa obcego og Bronisław Świderski i Asystent śmierci). De kan karakteriseres som intellektuelle og intertekstuelle læsninger af Danmark og danskere set både fra et ydre og det (kvasi-)indre perspektiv, begge bøger er også skrevet på polsk (og mig bekendt ikke oversat til dansk). De er kritiske og fulde af bitterhed, ikke politisk korrekte - meget direkte i deres samfundsdiagnoser. De gennemgående emner er fremmedhed - eller ifølge Świderski - den fremmedes grundlæggende erfaring: at det er fejlen som kommer før normen i hans/hendes tilværelse (Świderski 2012:111). Fejl og oversættelse er de vigtigste kategorier i en indvandrers "multi-biografi" (Świderski 2012:112). Świderskis hovedpersoner har tredobbelt identitet - polsk, jødisk og dansk. I romanerne er det legen med identiteterne og biografierne samt nødvendigheden af (i den transgressive situation hovedpersonen befinder sig i) at "anstrenge sig for hele tiden at oversætte/tolke sig selv" (Świderski 2012:111), der fremstår som hovedpersonernes centrale intellektuelle og eksistentielle øvelse.

Świderski skriver fra en position som ingen - hans hovedpersoner eksisterer ved siden af det danske samfund, på dets margen eller i dets skygge. Det at være ingen, dvs. ikke bundet af sine sociale tilhørsforhold, det at være en in-between figur (i den forståelse som Homi K. Bhabha præsenterer i The Location of Culture, 1994) - er for ham den eneste sociale position, som en forfatter bør tilstræbe. For den gør det muligt (paradoksalt nok) at være kritisk: over for alle andre, men i den grad også over for sig selv (Świderski 2012:419 f.). Og kritikken er for ham lig med verdens affirmation - "jeg skriver, fordi jeg tror på, at man kan ændre noget”, som forfatteren tilkendegiver i et interview (Świderski 2012:424). Hans hovedpersoner - som helt klart bærer forfatterens selvbiografiske træk (og romanerne kan beskrives som autofiktive) er udsat for en eksistentiel situation, hvor de - med Świderskis ord - mister deres biografi, som går tabt med det "gamle" sprog, og skal konstruere deres nye "multi-biografi" - bygget på fejl, fejltagelser og gentagelsen. Sproget, eller rettere sprogene: den gamle og den nye - tilskrives en central rolle ved denne proces ${ }^{6}$, som går ud på at skabe en identitet, samt genskabe, genskrive, lave nye og nye versioner af den. Hans hovedpersoner sætter sig mellem to stole: "Modersmålet har glemt indvandreren, det nye sprog - har ikke endnu begreber, som ville være præcise nok til at udtrykke hans individuelle oplevelser", , som forfatteren udtrykker det i sin essay "Doświadczenia emigranta"

${ }^{6}$ Świderski er - med inspiration i Kierkegaard - tilhænger af den procesuelle forklaring af den individuelle identitets væsen og af hvem et menneske er, nemlig: "en mulighed, et projekt, som er placeret i fremtiden", se: Świderski (2012:119).

${ }^{7}$ Citater fra Świderskis tekster kommer i min egen oversættelse. 
[En udvandrers erfaringer] (Świderski 2012:112). Det nye sprog gør det ikke muligt at udtrykke sig selv - den fremmede i Stowa... skriver i sit brev til dronning Margrethe d. 2.:

Ud over det vidste jeg, at min tavshed er - at den netop er min. At adlyde læreren [som ville have, at han gentog danske ord og sætninger uden at forstå dem, S.I.S.] var lige med at miste sig selv: at udtrykke sig selv ved hjælp af fremmede ord. (Świderski 1998:236)

Tavsheden bliver et tegn på modstand, men også en måde at beholde sin integritet på. En anden person i romamen - en polsk kvinde, som kommer til Danmark for at finde kærligheden, konstaterer:

(...) det var sproget [det danske sprog, S.I.S.], som stillede os mod hinanden. Jeg tænkte dengang, at hvis vi ikke kunne tale, så ville der ikke være nogen fremmedhedsfølelse, måske heller ingen krig. Vi ville ikke mistænke hinanden for løgn og hykleri. (Świderski 1998:187)

Sproget som byggesten for ens identitet og selvbiografi som en åben struktur er det som interesserer Świderski. Han er iagttager af det indre landskab, af den multi-biografi, som er følgen af et multinationalt liv og en erfaring på tværs af forskellige kulturbetingede selvforståelser, og som bygger på det at tage fejl og hele tiden at oversætte - rettere end det nostalgisk, sentimentalt at kigge tilbage på sit barndoms-/ungdoms land ${ }^{8}$.

\section{4. "NU IGEN FOREGÅR ALT UDEN MIN DELTAGELSE" - GRZEGORZ WRÓBLEWSKI}

Grzegorz Wróblewski (født i 1962) flyttede til København i 1985. Han er digter, maler, dramatiker og perfomer og medlem af Dansk Forfatterforening. Han debuterede i Polen - hans første digtsamling blev udgivet i 1992. Hans digterkunst er anerkendt i Polen, hvor han omtales som tilhørende den såkaldte brulion-generation'. Indtil videre har han udgivet 7 digtsamlinger på dansk (oversat/delvis oversat til dansk): Siesta på Nørrebro (1994) (på dansk v. Janina Katz og Uffe Harder), Hvis hver fluevinge er talt (1999), Kopenhaga (2001),

${ }^{8}$ Bronisław Świderskis datter - Maja Magdalena Swiderska (født i Danmark i 1976) er også forfatter. Hun har indtil videre udgivet to formeksperimenterende romaner The Border Breaking Bunch (2008) og Brudstykke (2011), hvor hun i posthukommelsens æstetik/poetik bevæger sig i de tabte mentale og identitetskabende landskaber ved at komme tilbage til sine jødisk-polske forfædres Polen.

${ }^{9}$ brulion var et polsk litterært tidskrift, som udkom i årene 1987-1999, hvor en række unge polske (og nu anerkendte) digtere og forfattere blev anmeldt og omtalt. 
Den ny koloni (2003), Soul Rebel (2006), Digte (2015) og Cindys vugge $(2016)^{10}$. I Siesta på Nørrebro giver han øjebliksstemninger, brudstykker fra hverdagen og små observationer, hvor København først og fremmest fungerer som en kulisse og sjældent trækkes i forgrunden, som fx i digtet "Valby Langgade": "Et bordel (250 kroner pr. næse)/et slagteri (en sødlig, vammel lugt)/En frisør (klipper oldinge der allerede er døde)/ det er mit danske landskab/og helt konkret Valby Langgade". Samme måde at konstruere digteriske billeder på finder man i de andre digtsamlinger - det danske "landskab" kommer til udtryk gennem stednavne, gadenavne, personernes navne, ellers dyrkes minimalistiske (med henblik på det poetiske sprog) notater fra små begivenheder og situationer, som bliver til metaforer (jf. Wilczyk 2010:11). Samlingen Kopenhaga (som er det polske navn for København) fra 2001, som består af 63 korte prosastykker ${ }^{11}$ er den første i prosaform, hvor Wróblewski direkte kommenterer sine indtryk fra det at være en del af den fremmede danske virkelighed. Ligesom i hans tidligere digtsamlinger er hans metode nærmest fotografisk - han tager billeder af situationer og indtryk set med en emigrants øjne (jf. Klejnocki 2005:506) og han benytter sig af en understatement-poetik - han hentyder kun til, men udtrykker ikke sine følelser direkte. Hans øjebliksstemninger, glimt fra det københavnske byrum, kan også læses som en form for "en antropologisk notatbog med rapporter fra København" (Pessel 2014:76). Martin Larsen indleder sin anmeldelse af samlingen med at understrege det ikke-danske ved den, og ved at afgrænse den erfaring, teksterne giver udtryk for, fra de indfødtes:

Hvad vil det sige at være polsk i Danmark. Først og fremmest (vil jeg tro) dette: Ikke at være dansk. Men hvad vil det så sige? Det vil sige, at se alting ske på en måde lidt forskudt fra den måde vi (indfødte) ser dem på, eller måske rettere at se det vi netop ikke ser. (Larsen 2001)

Wróblewskis prosastykker rummer iagttagelser, refleksioner og kommentarer, som vedrører almindelige, ofte ganske banale situationer - han maler det almindeliges landskab, eller som Anna Kałuża (2010:403) udtrykker det: han nedfælder "'"rå" og "tætte" etnografiske notater". De er realistiske, halvrealistiske og andre gange surrealistiske. De røber jegets utilpashed eller manglende samtykke (og vilje) til at absorbere den nye virkelighed og gøre den til sin, udtrykt gennem undren over små dagligdagssituationer ( $\mathrm{fx}$ det at hele tiden blive mødt med spørgsmålet "Hvor kommer du fra?", som skulle være et bevis på danskernes interesse for fremmede, som jeget/fortælleren dog nægter

${ }^{10}$ Han har ellers udgivet 12 digtsamlinger, 5 samlinger med poetisk prosa og 6 dramaer på polsk.

${ }^{11}$ Kopenhaga udkom også på polsk i en større samling tekster under titlen Pomytka Marcina Lutra (proza i szkice kopenhaskie) i 2010 [Martin Luthers fejltagelse (prosa og kortprosa fra København)] Jeg benytter mig af den polske udgave. 
at tro på) og kritikken af danske tabuer (som alderdom og død) og den danske velfærdsstat. Wróblewski trækker sig tilbage til det private og giver afkald på at henvise til større sociale systemer. København - foruden at være et geografisk sted, er også en sindstilstand (jf. Larsen 2001) for en til tider fortabt eksistens, som dæmper sin utilpashed med euforiserende stoffer. Han stiller sig selv spørgsmålet: "Er det bedre nogen som helst andre steder?" (et interessant spørgsmål)". Dermed sætter han sig i en komaagtig tilstand: det at være og samtidig ikke at være, at leve og samtidig helst ville skjule sig for omverdenen, som i følgende stykke:

Efterår. Denne årstid passer mig udmærket. I dagevis går jeg ikke ud. Jeg har et fremragende argument: Stormen og regnen som pisker ned, risikoen for halsbetændelse, depression på grund af skyggerne der bevæger sig alt for lavt... $\mathrm{Nu}$ igen foregår alt uden min deltagelse. Deres små lorterevolutioner uden for mine godt isolerede vinduer! $!^{12}$

Fortælleren i Kopenhaga og jeget i hans emigrantdigte er fremmedgjort og kan også siges at fremstille sig selv som fremmed. Det er alligevel en anden form for fremmedhed end hos Fenigsen, Katz og Świderski - fortælleren føler sig ikke som en flygtning, og kernen i konstruktionen af hans identitet er heller ikke baseret på de nationale præmisser (om han er polsk, dansk eller noget tredje er ikke centralt), men er bygget omkring det eksistentielle spørgsmål om, hvem han er. Det er hans individuelle, subjektive perspektiv og ikke det universelle (som i Frank O'Haras personism og banalisme, jf. Klejnocki $2005^{13}$ ), det er det lokale og specifikke, som sættes i fokus.

\section{HYBRIDE IDENTITETER, HYBRIDE LITTERATURER}

Begrebet "indvandrerforfatter", forstået som en, der "bare" giver vidnesbyrd om det ikke at være "herfra", synes at være for snævert til at rumme de fire forfatterskaber. Det, de fire forfattere har tilfælles, er, at de alle er af ikkedansk oprindelse, at de tematiserer det ikke at komme fra Danmark, og at de ikke er omtalt i dansk litteraturhistorie (med Janina Katz som undtagelse - hun nævnes fx i Nordisk Kvindelitteraturleksikon). Men der er også forskelle - det er kun Fenigsen og Katz, der skriver på dansk (og Katz er oversat til polsk, hun begyndte også at skrive på polsk et par år før sin død) og derfor er udgivet og anmeldt i Danmark. Świderski og Wróblewski skriver på polsk og sidstnævnte bliver oversat til dansk, men opnår dog ikke samme tilstedeværelse i det danske litterære kredsløb (det gør de til gengæld i det

${ }^{12}$ Den danske oversættelse citerer jeg efter Larsen, 2001.

${ }^{13}$ Selve forfatteren udtaler sig dog kritisk om at blive regnet med til o'haristerne - se interviewet med Wróblewski http://cycgada.art.pl/?p=324 (hentet d. 28.01.2014). 
polske, hvor de dog heller ikke fremstår som helt centrale figurer). Hvis man vender tilbage til de tematiske områder, som Lars Wendelius har nævnt (billedet af Sverige, flashbacks til hjemlandet, nation, historien og jeget, kulturmødet og den dobbelte identitet), kan man konstatere, at alle fire forfattere i mindre eller større omfang italesætter dem. Fx billedet af indvandrerlandet (her: Danmark) kommer som kontekst for fortællingen (som hos Wróblewski), viser sig i glimt (som hos Katz) eller er mere kritisk profileret (som hos Świderski og Wróblewski). Fenigsens narrativ kan siges mest at skrive sig ind i det indvandrerlitterære paradigme, med den forventningshorisont, som kan give etnografisk indblik i de fremmedes liv, skrevet indefra indvandrermiljøet. Den dobbelte (faktisk tredobbelte) identitet og multibiografi udgør hovedemnet hos Świderski, er vigtig i Katz' prosa og lyrik, men synes ikke at være af interesse i Wróblewskis tekster.

Spørgsmålet om en særlig form for indvandreræstetik kan muligvis alligevel besvares bekræftende. Der findes mange fællestræk hos de fire forfattere, som dog hver har sin egen poetik til at udtrykke og bearbejde indvandrer- og migrationserfaringen. Med udgangspunkt i de læste polsk-danske tekster kunne man supplere listen over de typiske interesseområder i migrationslitteraturen med (a) det selvbiografiske/det autofiktive element og (b) det sproglige - det at skulle oversætte sig selv (for at bruge Świderskis metafor), uoversætteligheden og det at være "barbar", samt (c) indvandrererfaringens banalitet.

Og til sidst - findes der en særlig polsk stemme i dansk litteratur? Der findes i hvert fald fire stærke stemmer, men jeg ville ikke vove at påstå, at the (Polish) subaltern kan tale, sådan han/hun bliver hørt ${ }^{14}$. Med de fire eksempler in mente kan bogbranchens argument mod at udgive indvandrertekster pga. for dårlig kunstnerisk kvalitet sikkert afvises, det er heller ikke det sproglige (altså ikke tilstrækkelig godt dansk) ${ }^{15}$, som kan forklare denne uhørbarhed. Det kan muligvis være et af de andre argumenter, som Søren Frank (2013a:208 ff.) præsenterer som mulige forklaringer på den relative usynlighed af litteratur skrevet af ikkeetniske danskere: mangel på kolonialhistorie - og dermed en ret homogen litterær tradition uden synlige multietniske træk og det danske bogmarkeds beskedne størrelse - dets tematiske og formelle konservatisme (hvor migrationslitteratur bliver opfattet som en niche) ${ }^{16}$.

${ }^{14}$ Małgorzata Zduniak-Wiktorowicz (2010:49 ff.) fastslår, at Skandinavien er et meget produktivt motiv i polsk udenlandsk litteratur og understreger, at forfatterne gerne sammenstiller deres gamle og den nye kultur, hvor det sproglige aspekt (sprog som grænsedrager) er en af de vigtigste faktorer.

${ }^{15}$ Se Frank (2013a).

${ }^{16}$ De andre faktorer er: et lille og svært sprog, Danmarks ry som et xenofobisk land med restiktiv indvandrerlov og for lav kunstenrisk (og sproglig) kvalitet af de indleverede manuskripter (se Frank, 2013a:208 ff.). 
Hans Hauge (2014) spår, at fremtiden for dansk litteratur er hybriditet, samt at litteraturen kommer til at opstå in-between. Forhåbentlig også i det dansk-polske berøringsrum i tiden, hvor polakkerne er den største indvandrergruppe i Danmark.

\section{LITTERATURLISTE}

Aidt, N. M. (2007). Forord. I: N. M. Aidt et al. (red.), Nye stemmer (s. 7-9). København: Gyldendal. Blüdnikow, B. (2005). Pigen fra dengang. Berlingske (1.02.2005). http://www.b.dk/kultur/ janina-katz-pigen-fra-dengang (hentet 20.07.2016).

Bukdahl, L. (2014). Y-Factor. Weekendavisen www.weekendavisen.dk/litteraturprisartikel/y-factor (hentet 25.03.2015).

Christensen, J. K. (2015). Janina, kære, Janina. Berlingske (13.01.2015). http://www.b.dk/ boeger/janina-kaere-janina (hentet 20.07.2016).

Fenigsen, A. (1982). Der var så meget. En fremmeds fortcelling. Gyldendal.

Fenigsen, A. (1989). Og på den anden side. Gyldendal.

Frank, S. (2012). Hvar er migrationslitteratur. Kritik, nr. 203, s. 2-10.

Frank, S. (2013a). Is There or Is There not a Literature of Migration in Denmark? I: W. Beheschnitt et al. (red.), Literature, Language and Multiculturalism in Scandinavia and the Low Countries (s. 197-223). Amsterdam: Rodopi (hentet fra AcademiaEdu).

Frank, S. (2013b). Interkulturelle forfattere i dansk litteratur. I: S. Frank, M. Ü. Necef (red.), Indvandreren $i$ dansk film og litteratur (s. 105-133). Århus: Forlaget Spring.

Hauge, H. (2013). Sættes indvandrerproblemer under debat i dansk samtidslitteratur? I: S. Frank, M. Ü. Necef (red.), Indvandreren i dansk film og litteratur (s. 12-45). Århus: Forlaget Spring.

Hauge, H. (2014). Kan indvandrere skrive litteratur?. Berlingske, 22.02.2014 (http://www.b.dk/ kronikker/kan-indvandrere-skrive-litteratur\#, hentet d. 28.06.2016).

Kałuża, A. (2010). Świat według G.W. I: (G. Wróblewski) Hotelowe koty. Wiersze zebrane z lat 1980-2010 (s. 389-405). Wrocław: Biblioteka Rity Baum.

Katz, J. (1991). Min moders datter. Brøndums Forlag.

Katz, J. (2004). Drengen fra dengang. København: Vindrose.

Katz, J. (2006). Moje życie barbarzyńcy. Warszawa: Jacek Santorski \& Co Agencja Wydawnicza.

Katz, J. (2006). Min spaltede tunge. København: Vindrose.

Katz, J. (2008). Pucka. Warszawa: Jacek Santorski \& Co Agencja Wydawnicza.

Katz, J. (2008). Pisane po polsku. Kraków: Wydawnictwo Austeria.

Katz, J. (2010). Skrevet på polsk. København: Rosinante.

Katz, J. (2010). Opowieści dla Abrama. Warszawa: Wydawnictwo Czarna Owca.

Katz, J. (2011). Powrót do jabłek. Katowice: Biblioteka Śląska.

Klejnocki, J. (2005). „Ciamkowatość życia”. Aspekty emigracyjnej codzienności w poezji Grzegorza Wróblewskiego. I: A. S. Kowalczyk (red.), Pisarz na emigracji. Mitologie, style, strategie przetrwania (s. 503-518). Warszawa: Elipsa.

Larsen, M. (2001). Leve på polsk. Information. https://www.information.dk/2001/11/leve-paapolsk (hentet d. 25.07.2016).

Larsen, P. S. (2006). Helt sin egen. Kristeligt Dagblad. http://www.kristeligt-dagblad.dk/ kultur/helt-sin-egen (hentet d. 20.07.2016)

Mohnike, Th. (2007). Der ethnographische Blick. Über Literatur und Kultur als diskursive Kategorien am Beispiel schwedischer Einwandererliteratur der Gegenwart. I: J. Adam et al. (red.), Transitraum Deutsch. Literatur und Kultur im transnationalen Zeitalter (s. 237-253). Wrocław-Dresden: Neisse Verlag.

Nilsson, M. (2010). Swedish 'Immigrant Literature'and the Construction of Identity. TijdSchrift voor Skandinavistiek, vol. 31, nr. 1, s. 199-218. 
Pessel, W. K. (2014). Literackie umiastowienie. Grzegorz Wróblewski - poeta (z) Kopenhagi. Teksty Drugie, vol. 6, s. 64-81. (http://rcin.org.pl/dlibra/publication?id=76813\&tab=3, hentet d. 06.12.2016).

Schab, S.I. (2016). Głos z "pustej przestrzeni". O recepcji debiutu Yahyi Hassana w Danii. Folia Scandinavica Posnaniensia, vol. 19, 201-212.

Simonsen, K. (2013). Migrationspoesi og litterære stereotyper. En imagologisk læsning af Eva Tinds do/. I: I: S. Frank, M. Ü. Necef (red.), Indvandreren i dansk film og litteratur (s.134-161). Århus: Forlaget Spring.

Skyum-Nielsen, Erik. (2011). Forsøg på forkortelse. Bøn om udsættelse. Information (2.09.2011). https://www.information.dk/kultur/anmeldelse/2011/09/forsoeg-paa-forkortelse-boen-udsaettelse (hentet d. 20.07.2016).

Stoubæk, R. M. Roman (2012). „Ich hatte viele Grenzen überschritten, um die zu werden, die ich nun war". Hauptaspekte der skandinavischen Migrantenliteratur. Ph.d.-afhandling. Universität Tübingen. https://publikationen.uni-tuebingen.de/xmlui/handle/10900/47056 (hentet d. 20.07.2016)

Świderski, B. (1981) Autobiografie. Londyn: Poets and Painters Press.

Świderski, B. (1998). Słowa obcego. Kraków: Znak.

Świderski, B. (2007). Asystent śmierci. Warszawa: W.A.B.

Świderski, B. (2012). Kiedy moge zabić? Dyskusje o kulturze i przemocy. (red. J. Borowczyk, M. Larek). Poznań: WBPiCAK.

Thing, M. (2013). Den jødiske indvandrer og litteraturen 1900-1970. I: S. Frank, M. Ü. Necef (red.), Indvandreren i dansk film og litteratur (s. 46-74). Århus: Forlaget Spring..

Wendelius, L. (2002). Den dubbla identiteten. Immigrant- och minoritetslitteratur på svenska 1970-2000. (=Uppsala Multiethnic Papers 46). Uppsala: Uppsala Universitet.

Wilczyk, W. (2010). Porcje i szkice. I: (G. Wróblewski) Hotelowe koty. Wiersze zebrane z lat 1980-2010. Wrocław: Biblioteka Rity Baum, s. 9-18.

Wróblewski, G. (1994). Siesta på Nørrebro. Brøndum, Aschehoug.

Wróblewski, G. (2010). Pomytka Marcina Lutra (proza i szkice kopenhaskie). Warszawa: Wydawnictwo Uniwersytetu Warszawskiego.

Wróblewski, G. (2010). Hotelowe koty. Wiersze zebrane z lat 1980-2010. Wrocław: Biblioteka Rity Baum.

Wróblewski, G. (2013). Wanna Hansenów. Poznań: WBPiCAK.

Zduniak-Wiktorowicz, M. (2010). Współczesny polski pisarz w Niemczech - doświadczenia, tożsamość, narracje. Poznań: Wydawnictwo Poznańskie.

\section{Sylwia Izabela Schab}

Uniwersytet im. Adama Mickiewicza w Poznaniu

Katedra Skandynawistyki

al. Niepodległości 4

61-874 Poznań

Poland

sylwias@amu.edu.pl 